\title{
OS PRIMEIROS SUBMINISTROS MUSICAIS DO BRASIL PARA O RIO DA PRATA $\because$ A RECIPROCI- DADE MUSICAL ENTRE O BRASIL E O PRATA. A MÚSICA NAS AÇÕES BÉLICAS. (De 1750 até 1855 , aproximadamente) $\left(^{\star}\right)$.
}

\section{FRANCISCO CURT LANGE \\ Diretor do Instituto Latinoamericano de Musicologia (Montevideo)}

Não se' sabe exatamente quando começou o Brasil a fornecer músicos para a Argentina colonial. Em realidade, este país se achava povoado por um número maior de portuguses do que o leitor poderá imaginar. Houve prateiros e marcineiros em Buenos Aires e Córdoba durante o período colonial, destacando-se estes artífices pelo primor dos seus trabalhos. Nas minhas pesquisas em Córdoba achei até a presença dum médico português. Também houve muitos Padres portugueses no clero regular ou conventual, especialmente entre os da Ordem Seráfica de São Francisco. Ainda hoje se encontram nos velhos mosteiros do Interior, pertencentes a esta grei de mendicantes, livros portugueses de Canto Chão, levados consigo para uso diário, ou comprados pela Província da Ordem, como o Theatro Ecclesiastico e Manual de Missas, de Frei Domingos do Rosário e o Processionale, ac Rituale Romano-Seraphicum ad usum Fratrum, ac Monialum S. Francisci, publicado em Lisboa em 1780. O anterior teve grande popularidade e chegou a muitas edições. $E$ isto, certamente, não exclui a possibilidade de se ter trazido em data anterior tais livros, ou edições anteriores, que desapareceram posteriormente das Bibliotecas por excesso de uso ou por acidentes diversos: Também devemos lembrar que as primeiras penetrações da Companhia de Jesus-se levaram a efeito quase simultâneamente, vindo uma do Brasil e a outra do Peru e Alto Peru (hoje Bolívia). E que os paulistas chegaram até as pa-

(*). - Dedico este pequeno trabalho aos meus queridos amigos D. Lia e Doutor Clovis Salgado. 
cíficas Missões ou Reduções de Indios, maravilhosamente civilizados após a sua catequese, levando com eles milhares de guaranis, homens, mulheres e crianças, para os empregar na escravidão. Entre estes foram, sem dúvida, muitos cantores e instrumentistas que havia em cada povo e que se fizeram famosos na Argentina colonial e fora de suas fronteiras, pela sua exclusiva dedicação à arte musical em conjuntos que ultrapassavam oitenta e mais intérpretes e grupos de magníficos dançantes.

Também encontrei no Arquivo Provincial de Mendoza, capital da Província de Cuyo, a relação dum grande número de cidadãos portugueses, feitos prisioneiros quando do assalto de Cevallos à Ilha Grande (Santa Catarina). Foram internados na região andina para os isolar de toda possibilidade de evasão. A sua quase totalidade, brasileiros natos, ficaram lá, casados na sua maioria com argentinas e, quando após a Independência da Argentina, foi ditada a obrigatoriedade de adotar-se a cidadania argentina ou de abandonar o país, eles ficaram e foram absorvidos pelo meio. O leitor deve ter presente que a definição "português" não significava de forma alguma, que tais elementos proviessem de Lisboa, do Porto ou de outros pontos da Lusitânia. Pelo contrário, a migração da quase totalidade destes homens, - migração forçada, - proveio do Brasil, embora juridicamente, até a Independência, os brasileiros. fossem considerados portugueses. Ninguém na Argentina, naqueles tempos, teria tido a preocupação de classificá-los como portugueses ou brasileiros. Havia nesses prisioneiros de guerra mineiros, cariocas, paulistas, catarinenses e alguns gauchos.

Devido à maior potencialidade do Brasil, especialmente com referência às duas capitais, Rio de Janeiro e Buenos Aires, nesta última, quando o Teatro público começou tomar forma, não faltavam contratações de músicos e cantores feitas no Rio para atuar na Capital da região do Prata. Quase simultaneamente apareceram individuos ou grupos de artistas dispostos a uma aventura artística, naqueles tempos ainda modesta, procurando mudar de meio e tentar a sorte em outras latitudes. A documentação colonial sumiu em grande parte nos dois países, particularmente com o incêndio dos respectivos teatros, e não podemos penetrar muito no passado sem achar um vazio quase total. E a extensão dos passaportes foi feita em form? muito primitiva, falhando muitas vezes na especificação da profissão. devendo-se dizer que o incêndio intencional da Cúria Metropolitana e das mais importantes igrejas de Buenos Aires durante o primeiro período do Governo de Perón, privou esta cidade duma documentação insubstituível e preciosa.

Em 1783, Carlos Recco, Mestre Organeiro, italiano, natural de Milão, solicitou do Vice-rei autorização para voltar ao Rio de Ja- 
neiro, o seu lugar de residência, logo após ter restaurado os orgãos de São Francisco de Montevideo e o dos Recoletos Buenos Aires (1). Montevideo (1).

Fora da referência de que por breve tempo foi mestre de capela da Catedral de Buenos Aires um tal Salinas de Lima, em 1806, qualificado de "português", nada importante acharemos no terreno eclesiástico, devendo dedicar a nossa procura ao teatro e à sala incipiente de concerto, e, sem que o leitor talvez o suspeite, aos casos bélicos entre as duas nações, e posteriormente, as duas unidas, juntos com o Uruguai, na Guerra da Tríplice Aliança, contra o Paraguai. Não pretendemos chegar além do ano 1852 , - data da derrota do ditador Rosas, - pelo incremento que tomou nos anos posteriores o intercâmbio entre os dois países, tendo geralmente por estação de pouso intermédio a cidade de Montevideo. Tudo dependia, em última análise, da evolução que no campo musical experimentavam estas capitais, prolongando-se logo as viagens artísticas até o Chile e o Peru. Desde a estréia da ópera $A b u l$ de Alberto Nepomuceno em Buenos Aires, até as atuações de Villa-Lobos em Montevideo e Buenos Aires e os famosos concertos dedicados aos compositores mineiros na Faculdade de Direito e Ciências Sociais da Universidade Nacional de Buenos Aires, na Rádio Nacional, na Catedral de Buenos Aires, nas Universidades Nacionais de Tucuman e Mendoza, no Teatro de La Plata, e no Teatro Solis cle. Montevideo, este intercâmbio aumentou consideravelmente e há-de exigir futuramente uma dedicação pormenorizada para trazer à luz interessantes aspectos destas peregrinações artísticas .

(1). - Archivo General de la Nación, Colonia, 9-12-8-12, Licencias y Pasaportes, Libro 13, PI-ROD, folio 274. O texto da solicitação é o seguinte:

Exm? S. or Virrey -

Carlos Recho [sic] Maestro organero de Nacion Ytaliana natural de Milan, a VE.a con el devido respeto, dice: aver venido del Rio Geneyro donde tiene su morada llamado a esta de Montevideo, y Buen.s Ayr.s para la recompocicion de los organos, lo que tiene a la presente ejecutado en los de S.n Fran.co y Recoletos de B.S. A.s y en este de S.n Fran.co de Montevideo y no teniendo en q.e exercitarce ni vuscar la vida solicita el permiso de VE. a para regresar a su Destino, por tanto

A VE.a rendidam.te suplica se digne consederle esta gracia a que quedará eternam.te reconocido rogando a Dios gu.e la vida de VE.a m.s a $:$ s Montev 2 Enero de 1783

$$
\text { Carlos Gaudenzio Recco }
$$

Al margen consta: Pasaporte para ir a la Bahia en la zumaca del mando de Man.I de Acunha El Buen Jesus a fin de trasladarse de alli al Jan ${ }^{\circ}$ - Se expidió en 11 de en ${ }^{\circ}$ de $83 .-$ 


\section{Música in tempore belli.}

Dom Miguel de Salzedo, sitiando em 1735 a Colônia do Sacramento, - maçã de permanente discórdia entre o Brasil e a Argentina, - a submeteu no dia 28 de novembro a intenso bombardeio e entusiasmado com a brecha que abriu na muralha da cidade,

$$
\text { "mandou um trombeta intimar à rendição" (2). }
$$

Nesta ocasião Colônia salvou-se pela negativa do Comandante, Pedro de Vasconcelos, e a oportuna entrada, a 6 de janeiro de 1736, de sete navios de guerra conduzindo reforços para os sitiados. Mais adiante, durante a Guerra da Espanha contra Portugal, aliada de Inglaterra, D. Pedro de Ceballos saiu de Buenos Aires com um exército de 2.000 homens, atacou a Colônia de Sacramento e a rendeu por capitulação a 2 de novembro de 1762 . Num documento da época descreve-se sua entrada na Praça forte:

"À uma hora do dia tocou-se para Assembléia do Acampamento, às duas horas para a marcha e assim a tropa se pốs em movimento na seguinte ordem: os lacaios de S: E. com cavalo coberto; quatro dragões de espada em mão, dois Capitães, o Capelão Mór e o Ouvidor de Guerra, todos a cavallo. Seguia-se-lhe o Maior General com 12 dragões a pé, e formados, duas trombetas, duas trompas, e os timbales, que iam alternando com as caixas e pífanos ou que batiam já a marcha dragona, já a da infantaria" (3).

$\mathrm{Na}$ famosa batalha de Ituzaingó, entre o exército argentino e oriental, de um lado, e o brasileiro do outro, que acabou com a derrota do Brasil, interveio do lado dos brasileiros um batalhão alemão, que teria, sem dúvida, uma boa banda, não mencionada na documentação. Dirigiu as operações o Tenente General Braun, também alemão. Desta batalha existem lembranças musicais dos dois bandos em luta. José Brito del Pino, Ajudante do General Alvear, comandante em Chefe do Exército argentino, transcreve no seu Diário de la Guerra del Brasil uma ordem do General Soler, de 31 de outubro de 1826:

"A instrução dos cornetas e tambores do exército se fará na Vanguarda da linha, a umas 300 varas dela, e não ha-de exceder pela manhã das nove, e pela tarde, das 3 às 5 ".

(2). - História do Exército Brasileiro. Estado-Maior do Exército. Brasília e Rio de Janeiro, 1972, vol. I, pp. 242.

(3) . - - Diario anónimo de la Campaña del Gobernador Ceballos contra la Colonia de Sacramento, Biblioteca Nacional, Sección Manuscritos, Doc. N? 5674: 
E o Coronel José María Todd, nos seus Recuerdos del Ejército de Operaciones contra el Emperador del Brasil, publicadas em Salta, em 1892, trazendo importante informação sobre a campanha, no di: que na marcha contra as forças brasileiras

“... tocou-se às quatro da manhã uma diana estrepitosa por todas as Bandas de Clarins... As Guardas saiam separadas com as suas caixas c a clarins, formando um concerto infernal".

A batalha travou-se a 20 de fevereiro de 1827. Poucos dias depois, o Boletín del Ejército Argentino assinala que

"... os instrumentos guerreros encheram o campo com as estrofas triunfais do Hino da Pátria, e continuando, executou-se a Marcha de Ituzaingó, composição tomada, entre outras, no campo de batalha, a 20 de fevereiro, e destinada a receber o nome da primeira ação bélica que tivesse lugar e que fosse ganha pelo Exército Imperial"' (4).

Segue-se agora uma afirmação que possivelmente nunca poderá ser esclarecida, - embora seja duma lógica absolutamente aceitável, - pois atribui-se a composição desta marcha ao próprio Imperador Dom Pedro I, que ele teria entregue à Banda das tropas para que a executasse após a primeira vitória sobre os argentinos. Quando se retiraram os corpos do exército brasileiro do campo de batalha, ficou abandonado um arcão, contendo várias peças de música, e dentro destas, a marcha foi selecionada pelos músicos argentinos, ensaiada e batizada com o nome da batalha que acabara de livrar-se. Baldrich, nâ sua Historia de la Guerra del Brasil diz o seguinte:

"Esta versão sobre a origem da Marcha de Ituzaingó é a corrente e a verdadeira, segundo as informações que recolhemos a respeito deste assunto. Esta peça histórica ainda se executa no Exército argentino, e foi durante muitos anos a Marcha Presidencial, tendo sido substituida, não faz muito, pela de nome Marcha de San Lorenzo".

E nos Recuerdos já mencionados do Coronel Todd, este diz, quando se refere à chegada da notícia ao Quartel General, dando conta que o General Rivera ocupara a Província de Misiones, que Alvear

(4) - Partes Oficiales, Archivo General de la Nación, Buenos Aires, Sala IV, 17-2-3. 
“... mandou tocar diana a todas as Bandas de Música, tambores e clarins do Exército... À nossa chegada concorreram todas estas bandas e muitos chefes militares a expressar as suas felicitações. Em pouco tempo soaram novas dianas no Quartel Geral que repetiram todos os Corpos. O Chefe do Estado Maior deu um sinal ao Quatro, e todas as forças fizeram atroar o ar com dianas, tocando especialmente a Marcha de Ituzaingó e outra que denominava-se La Prisionera".

Sobre esta segunda peça de música não se esclareceu se foi argentina ou brasileira.

No dia 26 de abril de 1827 celebraram-se na Igreja de São Domingos funerais solenes pelas vítimas "imoladas na defesa de nossa Pátria, tanto nas batalhas navais como nas campanhas de guerra", durante o conflito bélico com o Império do Brasil. As despesas originadas com motivo desta cerimônia fúnebre foram cobertas pelos visinhos da Paróquia de São Telmo e celebraram-se com toda solenidade. Às nove horas começou o Invitatório. Cantaram os senhores Picassari, Rosquellas e Vaccani.

Temos ainda referências sobre a guerra naval entre as duas nações. O Almirante Brown, famoso na Campanha do bloqueio naval brasileiro sobre Buenos Aires, teve uma banda embarcada na sua Nave Capitana e antes de se livrar batalha fazia tocar uma Diana de Gloria que era uma antiga canção inglesa que chamou-se The morning of St. Patrick's Day. Nós diríamos que também deveriam ser incluidos os irlandeses, por ser São Patrício o Santo Patrono destes. Já anteriormente, no combate do Buceo, Brown fez celebrar com música a batalha ganha pela fragata Hércules, para a qual foi transportado o Almirante após ter quebrado a perna com uma bala de canhão.

Não possuimos, ao menos presentemente, a menor informação sobre o período cisplatino, com a ocupação da terra oriental, porque o Marquês de Laguna, General Carlos Frederico Lecor, não deve ter trazido no seu exército apenas Bandas, mas também um batalhão de alemães mercenários com a sua banda própria, pois tais conjuntos foram reconhecidos sempre pela sua afinação, precisão e amplo repertório. Este período há de merecer uma pormenorizada dedicação nossa, mais adiante, porque Lecor trouxe também cantores, instrumentistas, atores e música manuscrita do Rio de Janeiro, para fazer mais agradável o seu estadio em Montevideo, incentivando as atividades teatrais e musicais.

A última nota que podemos oferecer neste capítulo refere-se à batalha que o Ejército Grande, mandado por Urquiza, ganhou con- 
tra Rosas em Caseros. Desta ação decisiva veio participar o $15^{\circ} \mathrm{Ba}-$ talhão de Infantaria do Exército do Brasil, com a finalidade de auxiliar o General argentino. Achava-se constituido por soldados alemães e uma Banda da mesma nacionalidade. Embora as Bandas aumentassem muito em popularidade e eficiência no tempo de Rosas, a do batalhão dos alemães que lutavam contra o seu exército deve ter sido formidável. Eis aqui a relação completa do corpo musical o qual, recrutado em Hamburgo, a 27 de março de 1851, acusava além dos nomes, a distribuição dos seus respectivos naipes (5):

Músicos: Gustav Lindner (Maestro), Carl Buschendorf, Carl Dechert, Carl Hake, Carl Hunger, Carl Tennenborn, Ferdinand Krammel, Friedrich L. E. Heidelberg, Gustav Apold, Heinrich Bennholz, Hermann Krollmann, Julius Braun, Mathias Michelsen, Michael Müller, Pineus Lazarus, Theodor Tiffert, Wilhelm Hennings, Wilhelm Schöler, Wilhelm Wander.

Trombetas: Ernst Runge, Georg Graupner, Marcus Schwennen, Sebastian Fischer, Ferdinand Kranz, Carl Maier.

Cornetas: Carl Koening, Carl Zibell, Friedrich Indorf, Heinrich Pihl, Hermann Lotz, Johann Hundertmark, Niels Waaben, Christian Schnack, Julius Volpert.

Tambores: August Kammer, Carl Friedrich Kinkforth, Carl H. Stibenardt, Christian Weidemann (Tambor Mór), Elias Hild, Johann Gottlieb Stiem, Soren Christian Sorensen, Eduard Beulke.

Diretor da Banda: Carl Jahn.

Chegando assim ao ano 1852, confessamos que há muito vazio para ser preenchido com documentação que ainda se acha à espera do pesquisador.

\section{Breves noticias do Período colonial - A Música profana.}

Faltam-nos bastantes informações da época colonial, difíceis de serem obtidas pelos motivos já expostos previamente. Com a inauguração do Teatro de Operas y Comedias de Buenos Aires, em 1756. houve uma contratação no Rio de Janeiro para a integração, com elementos brasileiros, do elenco de cantores e instrumentistas. São, ao menos, os nomes que se salvaram: os cantores João Faria, Theodoro da Costa, Marcos Mexia, João Sousa e um tal Silva, uma cantora,

(5). - Lemmers-Danforth (Major Fedor von), Die deutsche Legion von 1851 im Dienste des brasilianischen Kaiserreighs, Marburg, 1853. 
sileiros vindo para o Rio da Prata. Não pode haver dúvida sobre a afluência de outros elementos, como por exemplo, no caso do incêndio do Teatro do Padre Ventura, na Rua da Opera dos Vivos, do qual autorizados historiadores como Varnhagen e Múcio da Paixão dizem que foi fundado em 1747-48 pelo mesmo Padre corcunda, que regia uma companhia de mulatos. Esta sala pegou fogo em 1776 . Joanna e o rebeca Pereira. Sem dúvida houve maior número de braLevantou-se logo o Teatro chamado Opera nova, em 1776, o único que a Corte achou quando veio se instalar no Rio de Janeiro. Foi proprietário deste edifício e da sua exploração Manuel Luís Ferreira, que viera de Lisboa exercendo o ofício de barbeiro e fizera-se rico, galgando posições as mais elevadas. Protegido do Marquês do Lavradio foi, quanto ao teatro, ator, bailarino e tocador de fagote. Neste teatro, como no do Padre Ventura, gozavam de grande favor do público as obras do Judeu, mas fizeram-se esforços, especialmente durante o Governo do Vice-rei Luís de Vasconcelos, de 1779 a 1790, para introduzir a ópera italiana em versão portuguesa e óperas e comédias musicais propriamente portuguesas, das quais adquirimos num sebo em Lisboa, uma apreciável coleção de músicas que ilustram pela primeira vez este período obscuro do lirismo teatral brasileiro. Veja-se para isto o nosso trabalho, La Opera y las Casas de Opera en el Brasil Colonial, no número 44 do Boletín Interamericano de Música, Washington, D. C., novembro de 1964. Pelas referências recebidas de Buenos Aires, alguns destes mulatos (e mulatas, pois já cantavam mulheres no cenário), podem muito bem, pela falta de ocupação, ter tentado a sorte na capital argentina. Já em 1756, o empresário Saccomano trouxe "mulheres do Brasil para que cantassem", e estas foram, sem dúvida alguma, mulatas. Aconteceu um problema similar de migração artística quando do incêndio do Teatro de São João, em 1824, em conseqüência dos distúrbios políticos, como poderemos ver mais adiante. Há alguns nomes de músicos no período colonial brasileiro, estabelecidos temporária ou permanentemente na Argentina que foram deturpados ou espanholizados pelo meio bonaerense que parecem ter sido com bastante evidência brasileiros. Na Companhia que se formou no Coliseo Provinsional, construido em 1803, nos tempos do Vice-rei Sobremonte, encontramos uma cantora, Ana Carrera. Seguramente, o seu verdadeiro sobrenome seria Carreira.

\section{O Primeiro Período da Independência argentina (1810-1851).}

Aqui termina a nossa informação sobre a participação de brasileiros na música e no teatro argentino durante o período colonial. Começa, após a declaração da Independência do país o brilhante pe- 
ríodo da administração de Bernardo Rivadavia, do seu magnífico liberalismo e da criação duma série de sociedades educacionais, literárias, musicais e científicas, aumentando rapidamente a atividade musical, graças à presença crescente duma série de elementos valiosos, alguns nativos, outros estrangeiros e muitos destes vindo do Brasil, onde permaneceram alguns anos ou por período mais breve. Esta etapa, de grandes benefícios para as artes, veio satisfazer a verdadeira forma renovadora que sentia a população de Buenos Aires após o monopólio cultural absolutista da Espanha.

João Rademaker, diplomata brasileiro, chegou ao Rio da Prata em maio de 1812, e assistiu no Coliseo Provisional à apresentação do melodrama 25 de Mayo, que seguiu-se como entremês à representação de Alcira. A peça estava destinada a exaltar o espírito patriótico dos portenhos, glorificando a epopéia da Independência. Numa carta que Rademaker remeteu a Lord Strangford com data de 10 de junho de 1812, descreve o ato da seguinte forma:

"Para dar uma idéia a V. E. da forma de pensar os habitantes deste país, vou descrever-1he algumas cenas duma Comédia, ou melhor dito, Entremês, que seguiu-se após a apresentação de Alzira e que foi recebido com grandes aplausos pelo auditório. A primeira cena representa a América procurando despertar os filhos do estúpido letargo em que se acham postrados. Aparece na cena o espírito da Independência Americana, e todos se levantam violentamente... A segunda cena representa a sala do Vice-rei, onde este personagem se acha rodeado de rapazes cortesãos, $O$ Espírito da Independência Americana aparece e o Vice-rei e a sua comitiva, aterrados, vão caindo por terra... O Final da peça é descrito assim: O Gênio apresenta ao público a nova bandeira nacional, que é azul e branca, e o Entremês acaba com canções patrióticas, cantadas por todos" (6).

Um autor anônimo, que passou cinco anos em Buenos Aires e cuja identidade descubriu-se posteriormente, descreveu a atuação dos bailarinos Toussaint (estabelecidos mais tarde em Montevideo) (7), no Coliseo Provisional de Buenos Aires:

"Para os bailados temos aos Toussaint e a um corpo de ballet que compreende bailarinos cómicos portugueses procedentes do Rio de Janeiro. Executam-se agora ballets de conjunto em lugar do pas de deux e pas seul de uma ou duas figuras principais". 1910

(6). - Pillado (José Antonio), Buenos Airés colonial, Buenos Aires, (7). - Archivo General de la Nación, Buenos Aires, Sala VI, 17-2-3. 
O mesmo autor diz num outro trecho:

"Haveria motivo para esperar que pessoas tão afeitas à dança como os argentinos tivessem um corpo de ballet regular, mas não é assim. Até pouco tempo atrás foram interpretadas por bailarinos do Teatro do Rio de Janeiro que aceitavam contrato por breve período".

E o Capitão Joseph Andrews, que veio percorrendo a Argentina e Bolívia e esteve também anteriormente no Rio de Janeiro, fez um comentário do que viu na mesma sala:

"Os atores não passaram de medíocres. Representou-se uma cena de um bailado, durante o qual foi impossível não sentir-se contente quando estorou a desaprovação manifestada pelo público, vendo a um dos bailarinos de cabriola portuguesa, com um traje outré, que se achava em uso na Corte do Rio de Janeiro" (8).

As invasões inglesas tinham passado à História e a Independên. cia da Argentina estava consolidando-se, embora não fosse ainda total até não acabar a campanha do Norte e posteriormente, a conquista, desde Mendoza, do Chile e do Peru pelo General San Martín Em Buenos Aires se respirava um clima construtivo e otimista. O primeiro cantor de certa importância chegado em 1810 a Buenos Aires foi Pietro Angelelli. Não possuimos dele as menores referências sobre o seu itinerário de viagem desde a Itália até o Rio da Prata. Este barítono, depois de ter cantado com grande sucesso no Teatro alla Scala de Milão, em Veneza, Barcelona e Madrí, e finalmente no São Carlos de Lisboa, deve ter feito estágio, a nosso ver, no Rio de Janeiro, cidade que neste tempo se achava num esplendoroso desenvolvimento pela presença da Corte na terra de Santa Cruz. Em 1811, tendo recebido prodigiosos aplausos da sociedade portenha, Angelelli voltou novamente para a Itália, fazendo, como seria de imaginar, nova estadia no Rio de Janeiro. Seguiu-se a soprano Carolina Griffoni, que cantara com ele posteriormente em Lima, numa nova viagem empreendida no ano de 1814 .

Em abril de 1820 tinha chegado a Buenos Aires mais um dos precursores da atividade musical erudita na Argentina, o Professor Virgílio Rebaglio, italiano, de quem se dizia que provinha do Cantão - Ticino da Suiça italiana. Conheceu a Rivadavia quando este se achava de viagem pela Europa e teria sido atraido para a Argentina por esta figura protetora das artes e ciências. Chegou com partituras de Haydn, Mozart, Tritto, Paër, Dussek e outros, estabelecendo

(8). - Love (Thomas George), A Five Years Residence in Buenos Aires during the years 1820 to 1825 . By an Englishman, London, 1825. 
uma Academia de Música no mesmo ano em que o Padre José Antônio Picassari criou com o seu sobrinho, Juan Pedro Esnaola a Academia de Música y Canto e achando-se em vias de organização, para ser inaugurada em 1823, a primeira Sociedad Filarmónica por Esteban Massini. Não conhecemos as vinculações de Rebaglio com - Brasil, por ser ainda necessário empreender minuciosas pesquisas nos arquivos cariocas, pois será necessário achar pela mesma via as interconexões de numerosos professores uma vez que se ponha em prática uma remoção exaustiva de papéis velhos.

Uma figura de extraordinária importância para ser destacada foi José Amat. Alterando um pouco a ordem cronológica deste relatório cabe dedicar a este notável artista, virtual organizador $\epsilon$ alma mater da Imperial Academia de Música e Opera Nacional, um capítulo especial. Sustentam alguns historiadores, uns copiando outros, que a sua vinda verificou-se em 1848 e que veio $\mathrm{em}$ conseqüência da Guerra Carlista, na qual teria servido como Capitão. Disto não há vestígio algum. Mello Moraes Filho conta no seu livro Artistas do meu Tempo, a fuga de Amat de Espanha, onde foi posteriormente banido como traidor (9), fato que o Jornal Press, de Paris, confirma (10), mas Augusto de Freitas Lopes Gonçalves sustenta que veio com a idade de nove anos com os seus pais, "devido às perseguições que sofriam pelas suas convições políticas (11). Educando no Rio de Janeiro, integrou-se na alta sociedade, sendo aceito pelos seus múltiplos pendores. Se tivesse vindo menino, teria passado mais tarde à Espanha, onde foi aperfeiçoar-se em música, e colhido pela guerra civil, havendo tomado parte nela por vontade própria, fugiu para o Brasil

(9). - Ed. H. Garnier. Rio de Janeiro, 1904. Veja-se na página 71 a referência com o título Dom José Amat.

(10) . - Na Revista Contraponto, edição comemorativa do Centenário do Teatro Santa Isabel (1850-1950), se transcreve uma nota do Jornal Press de Paris, sobre o incêndio desta jóia de teatro, reproduzida no Diário de Pernambuco de 20 de dezembro de 1869. As informações sobre o estágio de Amat no Recife as devo ao meu querido amigo e colaborador permanente do Instituto Interamericano de Musicología, Prof. Valdemar de Oliveira, figura consular da cultura pernambucana, incluindo ele também retificações que se referem aos erros que acusa na obra de Aires de Andrade. José Amat jamais foi diretor do Teatro Santa Isabel, porém Empresário da Companhia que ocupou o Teatro. Também as referências sobre Amat na Bahia não se encontram completas no trabalho de Hebe Machado Brasil, A Música na Cidade do Salvador (1549-1900), Salvador da Bahia, 1969. Sílio Boccanera Júnior, na sua obra $O$ Theatro na Bahia (Livro do Centenário, 1812-1912), nos traz referências sobre a estadia de José Amat nesta capital em 1870, assim como Hebe Machado Brasil somente fala dos anos 1864 e 1867, com uma carência de informação lamentável.

(11). - Dicionário Histórico e Literário do Teatro no Brasil, Vol. 1 A, Editora Cátedra, pág. 138. 
quando o seu bando perdeu. Antes de prosseguir, devemos chamar a atenção sobre o fato de ter aparecido, no Jornal El Censor de Buenos Aires, com data de 20 de junho de 1816, um aviso do seguinte teor:

"Na rua do Quartel de Artilharia, três quarteirões da Imprensa dos Meninos Expostos e indo para o campo, na casa de D. José Amat vendem-se um forte-piano superior, um órgão. item, uma criada [preta escrava] e diferentes misteres duma casa".

Ve-se que este homem tencionava abandonar Buenos Aires, voltando para Espanha ou talvez, para ser mais preciso, para Catalunha, de onde provem este sobrenome. Há uma tentação em supor que poderia ter sido o pai de José Amat que voltaria para Espanha por ter tido idéias monárquicas, que naquela época não foram permitidas na nóvel República.

Seria inadmissível crer que o morador Amat de Buenos Aires teria sido o Amat estabelecido no Rio de Janeiro. O primeiro deve ter visto a luz no século precedente e ao segundo calculamos ter nascido em 1815, aproximadamente. É bem possível que Don José Zapata y Amat tenha chegado ao Rio de Janeiro em fins de 1848, porque no mês de janeiro do ano seguinte os jornais anunciavam a sua presença na terra de Santa Cruz. Dava-se a conhecer como professor de canto em diversas línguas e como compositor. Morava na Rua da Misericórdia $N^{o} 29$ e oferecia ao mesmo tempo um grande sortimento de música francesa, inglesa, espanhola e italiana, pois muitos músicos que se radicavam na América Latina aproveitavam a oportunidde para trazer consigo um grande sortimento de música impressa e até instrumentos musicais para facilitar, com a sua venda, um mais fácil estabelecimento no país escolhido. O Almanaque Laemmert o incluiu na sua relação anual desde 1850 até 1865 . Em 1852 cantou no $\mathbf{P a}-$ lácio perante o Imperador e a Imperatriz, dedicando à primeira damá do Brasil as suas Mélodies brésiliennes. A qualidade da sua voz foi sempre muito elogiada, sendo considerado pessoa muito atrativa, também como cantor em cena. Tipha estudado com os professores Arregui, Carlini, Bordogni e Manuel Garcia em Madrí e Paris, e tendo praticado o ensino da voz na Cidade-Luz e outras capitais da Europa. Em 1856 casou com uma dama da sociedade carioca, sua discípula de canto, que teve uma atuação brilhantíssima em todas as temporadas da Opera Lírica Nacional, desde 1857 até 1863, incluindo as duas primeiras óperas de Carlos Gomes. Neste mesmo ano partiu Amat para o Sul, indo para Buenos Aires e Montevideo, onde desenvolveu uma prodigiósa atividade de professor de canto, regente de canto coral, empresário ocasional, organizador permanente de espetáculos, editor duma revista e compositor. Chegou à Argentina em fevereiro ou março, oferecendo o seu primeiro concer- 
to acompanhado pela cantora italiana Ida Edelvira, que o grande maestro Gioacchino Giannini levou para o Rio de Janeiro em 1849, resolvendo ela fugir da epidemia de febre amarela que vinha dizimando não apenas a população mas também os quadros líricos. Chegou a Buenos Aires em 1851, tendo trabalhado de qualquer forma porque no mesmo ano queimou-se o Teatro São Pedro de Alcântara, deixando muita gente sem ocupação até se organizar funções no Teatro $S$. Januário e posteriormente no chamado Teatro Provisório. No momento da chegada de Amat, a Sociedad Filarmónica de Buenos Aires passou por séria crise quando o seu diretor, Alejandro Marotta, retirou-se dela, estabelecendo-se com outra sociedade similar em aberta rivalidade. Nesta oportunidade foi nomeado para o mesmo cargo José Amat, dirigindo-a e administrando-a e organizando um coro misto de sessenta vozes, mudando a sede para um edifício novo, responsabilizando-se pela contratação de Sigismund Thalberg, se não houvesse sido pelo garibaldino Coronel Silvino Olivieri, naquela época radicado no Rio de Janeiro, quem dirigiu-se a Amat sugerindo-lhe que contratasse Thalberg para atuações em Buenos Aires. Publicou o períodico musical La Lira Argentina (1854) e uma Gramática musical (1855), promovendo as primeiras apresentações da Zarzuela Grande, com obras de Barbieri, Olona e Hernández, Olona e Gaztambide e tomando ele mesmo parte em Jugar con Fuego de Barbieri, uma atividade que já tinha iniciado no Rio de Janeiro e que ia continuar, procurando estimular aos compositores nacionais para se manifestarem em língua vernácula. Na Sociedad Filarmónica estabeleceu uma Escola de Canto de ensino gratuito e atuou na sociedade portenha como professor de canto, havendo tido numerosíssimos discípulos de ambos sexos. Cabe citar que Amat, além da sua periódica apresentação nos concertos da Sociedad Filarmónica, colaborou também nos cinco concertos de Thalberg com o seu coro e como cantor, junto com várias discípulas.

Tendo resolvido sua partida de regresso ao Brasil, Amat deu um concerto de despedida, partindo a 12 de setembro de 1856 para o Rio de Janeiro. Mencionamos estes fatos porque a fecunda atividade deste dinâmico e capacitado organizador, vocalista e compositor não tem sido suficientemente apreciada, embora se saiba que a proteção que ele deu à ópera em sí e à ópera nacional com particular ênfase, foi o primeiro passo para um nacionalismo que na época do predomínio e do fanatismo pela ópera italiana parecia esforço condenado a morrer. Amat tinha também se radicado temporariamente em Montevideo entre 1853 e 1856, onde dirigiu uma Sociedad Filarmónica, introduzindo, como em Buenos Aires, o gostu pelos clássicos e românticos alemães, o que fala muito a seu favor pelo seu senso de contemporaneidade. Em 1864 realizou uma viagem sob auspício oficial brasileiro para Europa, com o propósito de trazer um grupo de 
cantores para reestabelecer a Opera Nacional, fenecida por razões diversas. Fracassou na sua tentativa. Em 1866 realizou, ao que parece, outra viagem e de volta da Europa, passou para Buenos Aires e fez declarações altamente favoráveis sobre o Teatro Colón (o primeiro), construido durante a sua ausência de dez anos, assim como sobre a estreia de Fausto, que verificou-se no mês de setembro do mencionado ano, lendo-se na entrevista que deu que estivera em Londres, onde vira também o Fausto no Queen's Hall (12). Em 1869 apareceu como empresário dos espetáculos do Teatro Santa Isabel do Recife, que ardeu a 12 de novembro desse ano, perdendo uma verdadeira fortuna em trajes, partituras e outros materiais cênicos. Nada se sabre sobre os últimos anos da sua existência, que constitui problema a ser resolvido por pesquisas. Foi autor das óperas L'autre Waterloo e Il Gondoliero, escreveu numerosas obras para canto e piano, conno Noches del Plata, Las Hijas del Plata, Les Mélodies brésiliennes, Les Nuits brésiliennes, uma Fantasia para piano Recuerdos de España, numerosas Modinhas e outras peças líricas. Amat conseguiu galvanizar o interesse da sociedade carioca e da portenha em torno da música erudita e prestou um serviço extraordinário em prol da evolução musical dos nossos meios.

O caso José Amat (pai?) e José Amat (filho?) nos obrigou adentrarmos em meiados do século quando ainda não tínhamos feito relação alguma dos seus começos nos anos vinte. Reconhecemós que a movimentação de artistas se produziu somente numa só direção, de Norte para o Sul, ao menos nas primeiras três décadas, desde a Independência da Argentina, exetuando um caso em que o rabequista italiano Francisco Inácio Ansaldi passou em 1810 de Montevideo para - Rio de Janeiro, ingressando bastante mais tarde na Real Capela, onde aparece até 1828 . Vamos agora nos ocupar das primeiras grandes figuras que pisaram terra argentina vindo do Rio de Janeiro. Nos últimos dias de dezembro de 1822 , procedente de Montevideo, porém tendo saido anteriormente do Rio de Janeiro, chegou a Buenos Aires o famoso violinista Santiago (Giacomo) Massoni, acompanhado pelo instrumentista (flauta, clarinete, guitarra e mais alguns instrumentos) Estéban (Stefano) Massini e a senhora deste que foi cantora. Consta que os dois artistas homens atuaram uns dois anos ao serviço da corte do Rio de Janeiro, pois verificamos no Arquivo Nacional do Rio de Janeiro os seus nomes no rol de pagamentos como músicos de câmara da Corte. Chegaram à Argentina antes do incêndio do Teatro São João, que verificou-se dois anos mais tarde. A Senhora de Massini deve ter atuado na cena lírica carioca. O estágio prévio dos três em Montevideo, e certa freqüência com a que eles voltavam para aquela praça com atuações esporádicas, teve como

(12). - Diário La Tribuna, Buenos Aires, 19 de setembro de 1866. 
resultado o casamento de Massoni com a irmã do pianista uruguaio Federico Planel. Massoni nasceu em Bolonha em 1798 e iniciou em 1804 os estudos musicais na sua cidade natal, no que é hoje o Liceo Musical Rossini e do qual, o próprio compositor foi aluno dois anos mais tarde. Em 1808, Massoni ingressou no Conservatório de Milão, onde foi aluno de Bonifácio Asioli. Em 1813 ouviu o célebre Paganini nessa cidade e parece que recebeu dele lições, porque dizia-se aluno do virtuose. Começou como violino spalla nos Teatros de Bolonha e Torino, passou para Espanha e Portugal, atuando com grande sucesso em Madrí e no Porto. Em 1820 veio para o Rio de Janeiro como spalla da Opera e da Capela Imperial. No fim do período cisplatino embarcou para o Rio da Prata. Debutou, acompanhado pelo compositor argentino Juan Pedro Esnaola, na antiga Sociedad Filarmónica e na chamada Sala do Consulado. Foi-lhe confiada a regência da orquestra do Teatro (ou) Coliseo Provisional, que ele aumentou para 28 figuras, estreando em Buenos Aires o Barbeiro de Sevilha de Rossini em 1825 e o Don Juan de Mozart em 1827. Neste ano abandonou a Argentina, indo com o violoncelista Amadeo Gras, que era também notável pintor, para Mendoza, Santiago do Chile e Lima. Em 1833 realizou uma viagem artística como regente de uma Companhia de Operas, indo para Macau, Cantão e Calcutá. Viajou também para a Cidade do Cabo, e obteve grande sucesso em Londies. Morreu em Turim no ano de 1878. Massoni teve o mérito de escrever as suas Grandes Variaciones del Triste y del Cielito para violino e piano, e outra obra titulada Variaciones sobre el Gallinazo, as duas obras baseadas no folclore argentino e peruano, respectivamente. Com a estadia de dois anos no Rio de Janeiro, não nos causaria espanto se também no Brasil houvesse criado algumas obras baseadas no ambiente popular.

Estéban Massoni nasceu em Gênova, em 1788 e morreu em Buenos Aires em janeiro de 1835. Notável músico, foi mestre de várias gerações de músicos argentinos e particularmente de guitarristas-compositores: Estéban Echeverría, Nicanor Albarellos, Fernando Cruz Cordero, Juan del Campillo e muitos outros mais. Foi partidário do ditador Rosas, permanecendo no país e escrevendo para este um hino laudatório, o Himno de los Restauradores, escrito originariamente para voz e piano, e levado aos poucos para grande orquestra, constituindo-se numa peça de enorme popularidade e de eficaz proseletismo político. Foi autor duma série de canções, peças para guitarra, etc.

Chegamos agora à terceira e importante personagem que veio do Rio de Janeiro para o Prata: Mariano Pablo Rosquellas. Nasceu este músico exepcional em Madrí em 1790 e faleceu em Sucre, Bolívia, em 1859. Este artista teve uma atuação extraordinária em 
Buenos Aires entre 1823 e 1833 . Foi violinista, cantor (tenor), diretor de orquestra e de espetáculos operísticos. Formou-se na capital de Espanha e atuou alí, em Barcelona e Paris com grande êxito, sendo nomeado por Fernando VII primeiro violino da sua Câmara Real em 1815. Seu irmão Andrés Rosquellas (1781-1827), também foi um dos primeiros violinos na referida capela. Em 1806 casou em Madrí com Polônia Muñoz, tendo nascido deste primeiro matrimônio o seu filho mais velho, Mariano, que chegou a estabelecer-se em Buenos Aires. Rosquellas foi muito apreciado pelo monarca que para testemunhar-lhe a sua admiraçz̃o, presenteou-o com um magnífico Stradivarius. Tendo ficado viuvo e achando-se na Irlanda, casou com Letícia de Lazy, em 1818, sendo ela descendente do Conde de Lazy, General dos exércitos da Espanha no século XVIII. O casal chegou ao Rio de Janeiro aproximadamente em 1822, organizando nesta capital concertos na Corte. Está fora de dúvida que foi um protegido đo Príncipe D. Pedro. A sua atuação ficou até pouco completamente ignorada nos anais da História musical brasileira. Em 1823 nasceu o seu filho mais moço Luís Pablo, fruto de uma união ilegal do futuro Imperador Dom Pedro I com uma dama da sociedade carioca. D. Pedro confiou o menino aos cuidados do casal Rosquellas para a sua criação e formação e certamente, o mesmo deu cumprimento fiel ao encargo, guardando ao mesmo tempo o maior sigilo sobre o assunto. Em Buenos Aires, Luis Pablo estudou com o seu pai adotivo e Santiago Massini, apresentando-se em público com uma exibição impar de musicalidade e desenvolvimento cênico que indubitavelmente deve ter herdado do seu pai legítimo, pois Pedro I brilhou sempre pela enorme facilidade com que apreendia tocar vários instrumentos, e que manifestou-se também na composição.

Blas Parera, autor do belo Hino Nacional Argentino, teve o propósito de se transladar ao Brasil para aperfeiçoar-se com Marcos Portugal na composição. Esta foi sem dúvida a sua intenção, embora não lhe fosse possivel levar a bom termo o seu propósito. No Archivo General de la Nación conserva-se um documento do seguinte teor:

Dom Blas Parera, professor de música, suplica a V. E. queira permitir-lhe passar para o Rio de Janeiro, onde existe o imortal Marcos Antônio Portugal, de cuja instrução aguarda poder estender os seus conhecimentos numa arte com a que poderá ser de utilidade nesta capital (13).

O conhecimento que Blas Parera teve de Marcos Portugal não podia ter-se produzido por referências periodísticas que naquela época

(13). - Torre Revello (José), Un interesante documento sobre Blas Parera, in "Logos", Revista de la Facultad de Filosofía y Letras, No 10-11, Buenos Aires 1954. 
foram muito limitadas, tanto no Rio de Janeiro como em Buenos Aires, devido à introdução de uma imprensa rudimentar após o início do século XIX. Sabemos que nos primeiros periódicos argentinos não apareceu referência alguma sobre Marcos Portugal. Parera deve ter conhecido a fama deste grande operista por referências verbais muito elogiosas e pelos trechos de óperas que foram cantados na capital argentina com bastante frequiência. Não imaginava, naturalmente, a figura orgulhosa e petulante do compositor português, que jamais teria dodo aulas a um mestre chegado de Buenos Aires, menos ainda no seu apogeu, incentivađo por D. João VI. Blas Parera, pela sua adesão à causa realista, abandonou a Argentina ao redor de 1818, porque em agosto deste ano chegou a Cádiz, falecendo em Barcelona pouco depois de 1830.

Em 20 de fevereiro de 1822 chegou Rosquellas a Buenos Aires e já no dia 28 apresentou-se com grande sucesso no Coliseo Provisional. Não tinha uma grande voz, mas foi duma extraordinária habilidade para aproveitar os seus recursos muito inteligentemente. Foi um consumado ator e sabia sempre entrar em cena cuidadosamente trajado. Em 3 de março regressou para o Rio de Janeiro com a finalidade de trazer artistas daquela capital para aumentar os quadros destes em Buenos Aires, deixando nesta capital o seu filho mais velho Mariano. Voltou em 7 de junho trazendo consigo o barítono Miguel Vaccani e o dançarino José Maria Touissaint. A senhora deste, Madame Carolina Touissaint veio mais tarde e o casal apresentou-se a 11 de novembro de 1823 no Teatro Provisório. José Maria Toussaint regressou mais tarce ao Rio de Janeiro e em 1833, Carolina, voitou sozinha na Companhia de Felipe Catón. O seu marido aparece na década dos 40 integrando o ballet do Teatro Regio de Turim. Letícia de Lazy chegou a Buenos Aires em meados de dezembro de 1524. Com os elementos já estabelecidos na captial, os irmãos Tanni, Juan Antônio Vieira e o Miguel Vaccani, atuando Rosquellas de tenor, este começou oferecendo trechos de óperas italianas com os quais os auditórios ficavam embevecidos. Ganhou também um litígio com o empresário do Coliseo e formou uma sociedade composta de três membros, podendo ele dispor desta forma da sua própria atuação e estabelecer as bases de cooperação permanente que fixou para este triunvirato, sendo os seus sócios os senhores Munilla e Moreno.

Após a apresentação de árias, duetos, aberturas para orquestra, etc., Rosquellas iniciou a estréia de óperas completas com o Barbeiro de Sevilha (1825), continuando com mais algumas deste compositor tão popular como La Cenerentola, L'Inganno felice, La Italiana in Algeri, Tancredo e Otello, seguindo logo com o Don Juan de Mozart (1827), e Giulietta e Romeo de Zingarelli. Ainda sublimou-se mais fazendo estréia de fragmentos dos oratórios Mesías, 
Judas Macabeo e Sansón de Händel, e da Criação de Haydn, demonstrando possuir excelentes condições de regente, embora tenha estado a regência geralmente nas mãos de Massoni. Seu filho Luis Pablo causava sensação como cantor e pianista precoce e interveio com alguma freqüêencia nos espetáculos públicos, inclusive em Montevideo, sendo sempre apresentado pelo seu pai, primeiro aos sete anos e em seguida, também como compositor, fazendo estréia de quatro valsas dedicadas a quatro diferentes meninas da sociedade portenha, tendo sido publicados com os títulos La Clara, La Eufemia, La Carlota e La Cristina pela Sociedad Filarmónica. Exibia uma musicalidade fora do comum, junto com um desenvolvimento cênico admirável.

Mariano Pablo Rosquellas foi também muito apreciado como compositor. Apresentou em 1826 a ópera El Califa de Bagdad, escreveu a Sinfonia $A$ Batalha de Argel (1831), outra, de muita atualidade, La Batalla de Ayacucho para orquestra e banda militar (1832), Variações para violino e orquestra (1823), uma Grande Cantata (1827), e $O$ Pampero (1828), fazendo sem dúvida alusão ao terrível vento que açoita às vezes o Rio da Prata causando o naufrágio de numerosos navios e que é conhecido no Rio Grande do Sul pelo nome de "Minuano". Também escreveu Si la Mar fuera tinta, Variações para violino e orquestra (1830), uma Canción de Fructuoso Rivera (1839) e El que sin amores vive, canção que gozou de enorme popularidade. Devido a una série de desgostos e do agravamento da situação política, com a conseguinte diminuição das atividades artísticas, Mariano Pablo Rosquellas ausentou-se definitivamente da Argentina para estabelecer-se ná Bolívia. Permaneceu um tempo em Tucumán, onde o Governador Heredia fez construir expressamente um teatro para a sua atuação. Na Bolívia dedicou-se à exploração de minas de prata em Potosí, visitou o Chile e o Peru e radicou-se definitivamente em Sucre, sem abandonar jamais a sua dedicação às artes e às letras, fundando em 1835 a Sociedad Filarmónica Dramática.

Luis Pablo, logo após ter atuado no teatro lírico, cantando obras de certa dificuldade com o seu pai e com o cantor Luis Foresti, uma vez radicado em Sucre, teve destacadíssima atuação pública. Graduou-se em Direito e chegou a Ministro da Suprema Corte de Justiça; foi professor de Direito da Universidade de Sucre, Consul da Bolívia em Tacna e Secretário de Legação em Lima. Nesta capital casou, em 1845, com Teresa Torre Tagle, dama de família limenha muito ilustre. Voltou para Bolívia, sempre achando tempo para dedicar-se, mesmo ocasionalmente, à composição de música de certo fôlego, como as suas Variações sobre Árias Nacionais da Bolívia, uma Misa Maior para coro e orquestra, uma Fantasia para piano e diversos Hinos. Em 2 de junho de 1859, a esposa de Mariano Pablo Rosquellas faleceu subitamente dum ataque do coração. O filho "Pablito", como foi chamado outrora carinhosamente, em Buenos Aires, 
achava-se no seu cargo diplomático em Lima. Um mês mais tarde, em 12 de julho de 1859 , veio falecer dum violento ataque de pneumonia Mariano Pablo. Os restos do casal foram sepultados na Capela do Hospital Público de Sucre, por ter sido benfeitores da instituição. Em 8 de julho, Mariano Pablo fez testamento, constando no mesmo, entre a relação de bens que lhe deviam, que a Marquesa Daponte e Dona Lúcia Menezes de Sotomaior ou os seus respectivos herdeiros receberam do casal brilhantes e dinheiro num total de 45.000 pesos e que esta quantia foi declarada perante o escrivão Castro, com escritório na Rua do Rosário, em favor da sua esposa D. Letícia Lazy.

Conclui assim um episódio interessantíssimo, no qual se achava envolvido o próprio Imperador Pedro I. Cabe ainda acrescentar que na Cúria Metropolitana do Arcebispado do Rio de Janeiro consta o batismo de Luis Pablo:

"Aos vinte e oito do mês de agosto do ano de mil oitocentos e vinte e três nesta Igreja Matriz do Santíssimo Sacramento baptisei e puz os Santos Oleos ao innocente Luis Paulo, nascido na Freguezia a vinte e cinco de abril deste Anno, filho legitimo de Paulo Rosquellas, natural de Madrid e da sua mulher Leticia Rosquellas natural da Irlanda, moradores na Parroquia. Foram padrinhos os Excellentissimos D. Luis de Saldanha da Gama e Dona Arcangela Castello Branco. E para constar lavra-se este assentamento que assigno. O Coadjutor José Simões da Fonseca” (14) .

Nos anos vindouros Rosquellas será recordado como o pai do estabelecimento da Opera em Buenos Aires, dizia o British Packet and Argentine News em 1827. Efetivamente, o casal Rosquellas, com "Pablito", movimentou-se fidalgamente através do Brasil, da Argentina e de Bolívia, deixando atrás de sí a semente do bem artístico que mais tarde iam recolher as gerações futuras.

Mariano Pablo Rosquellas tinha chegado ao Rio de Janeiro em fins de 1818 onde desenvolveu grande atividade durante todo o tempo da sua permanência. Sustenta Ayres de Andrade que o seu verdadeiro nome era Ayres Leclicia Rosquellas, o que é grosso erro (15). A partir de janeiro de 1819, com a apresentação da ópera de Puccitta $A$ Caçada de Henrique IV, em espetáculo de gala como motivo do aniversário de D. Leopoldina, Rosquellas fez a sua apresentação, sem dúvida muito feliz. Nos anos seguintes, até a sua mudança para

(14). - Gesualdo (Vicente), Pablo Rosquellas y los Orígenes de la Opera en Buenos Aires, Editorial Artes en América, Buenos Aires, 1962.

(15). - Andrade (Ayres de), Francisco Manuel da Silva e seu tempo (1808-1876). Uma fase do Passado musical do Rio de Janeiro à luz de novos Documentos, Edições Tempo Brasileiro Ltda., Rio de Janeiro, 1967, Volume I. 
Buenos Aires, um número considerável de óperas foi apresentada por ele, mormente as de Rossini numa grande série. Geralmente foram oferecidas como espetáculos de gala com motivo dos aniversários da família real, D. Carlota Joaquina, D. João VI, e como benefícios. Coube a Rosquellas atuar com Joño e Maria Teresa Fasciotti, Miguel Vaccani, o fenomenal baixo brasileiro João dos Reis Pereira, Justina, Carolina, Elísia e Fabrício Piaccentini, este último como baixo cômico. Também atuou com Nicola Majoranini e Salvatore Salvatori, constituindo sempre elencos notáveis. Fez com estas óperas estréia absoluta no Brasil. Assim, em benefício da Fasciotti apresentou $O$ Barbeiro de Sevilha e em seu o Don Giovanni de Mozart. Em 1822, numa reprise do Don Giovanni, Maria Graham, que assistiu à apresentação na sua condição de Governante da Princesinha D. Maria da Glória, escreveu no seu Diário que "Rosquellas é um nome conhecido nos dois lados do Atlântico". Em 10 de dezembio de 1822, para a solenidade da coroação de D. Pedro I, ofereceu em espetáculo de gala Elisabetta, Regina d'Inghilterra, e em 9 de janeiro de 1823, também em espetáculo de gala, em comemoração do "Fico", Adelaide di Borgonha, data em que entram em completo declínio as apresentações de óperas completas em virtude de medidas econômicas restritivas impostas logo após a Independência do Brasil. Naquele tempo existiam duas companhias de Óperas, o que produziu, inevitavelmente, um conflito no Teatro São João, fosse pelos ensaios ou pela data de apresentação de cada espetáculo, e mesmo por rivalidades que jamais faltavam. Sem dúvida a razão para mudar-se Rosquellas para a Argentina indica esses motivos. Fez bem porque o incêndio do Teatro São João em 1824 levou a crise do teatro lírico a um verdadeiro colapso.

Há uma aparente contradição entre o conteúdo do testamento feito em Sucre, em 1859, pelo precursor da ópera no Brasil e na Argentina, por um aviso que apareceu no Diário do Rio de Janeiro, citado por Ayres de Andrade:

"Madame Rosquellas, em nome do seu marido Paulo Rosquellas, que se acha ausente, participa a todos os Srs. que se dignaram interessar-se na rifa de um Bandó de brilhantes, que se anunciou para correr com a loteria do Theatro de São João, e não se podendo efetuar este negocio, tenham por bem os ditos Srs. interessados concorrerem com os seus bilhetes à casa do anuncianto na Praça da Constituição, n $n^{9} 74$, para receber o seu importe".

Temos a impressão que o casal Rosquellas levou sempre uma vida de grande solvência, o que fica demonstrado no referido testamento, ao confiar à Marquesa Daponte e à $\mathrm{D}$. Lúcia Menezes de Sotomaior brilhantes e dinheiro num total de 45.000 pesos (bolivianos, chamados fortes). A venda do bandô por meio duma loteria 
poderá ter obedecido a uma aflição momentânea, motivada talvez pelos preparativos de viagem para o Sul, porém também por uma simples especulação. $O$ anúncio do jornal corresponde sem dúvida aos primeiros meses de 1822. Percebe-se também que as eventuais despesas de viagem que teve que facilitar ao barítono Miguel Vaccani e ao bailarino Auguste Touissaint, quando da sua radicação definitiva, se fez sem aflições monetárias como explica novamente o testamento. O comentário de Ayres de Andrade, dizendo que os artistas não podiam viver só de arte é critério errado no caso dos Rosquellas, assim como é errada a sua afirmação de que Mariano Pablo foi baixo. Os comentários públicos coincidem sempre que foi um tenor de voz deliciosa. Auguste Toussaint o acompanhou virtualmente em todos os espetáculos, inserindo nas óperas um número especial em forma de bailado: Ulisses e Penélope, Asis e Galatéa, Apeles e Campaspe, $O$ estudante feito painel, $O$ Desertor francês, Amor na Aldeia e mais outros. Nos pas de deux foi partenaire da sua esposa.

Cabe ainda adir que a ópera de Rosquellas, El Califa de Bagdad (O Grande Califa de Bagdá) deve ter sofrido modificações durante o seu estágio no Rio de Janeiro, pois no libreto, do qual se acha um exemplar na Biblioteca Nacional do Rio de Janeiro e que traz uma explicação, há referências a apresentações na Françà e na Espanha. Tais modificações foram motivadas pela redação dum novo libreto, do qual se encarregou o Dr. Luís Vicente De Simoni, que na Arcádia carioca teve por nome o de Dermino Lubeo. Foi figura de relevo nos meios literários e da medicina na capital brasileira. Reduziu a este drama joco-sério, baseado no livro do mesmo cognome espanhol, a unı drama formal em dois atos. Para finalizar este capítulo, seria talvez conveniente citar as óperas completas apresentadas por Rosquellas no Rio de Janeiro:

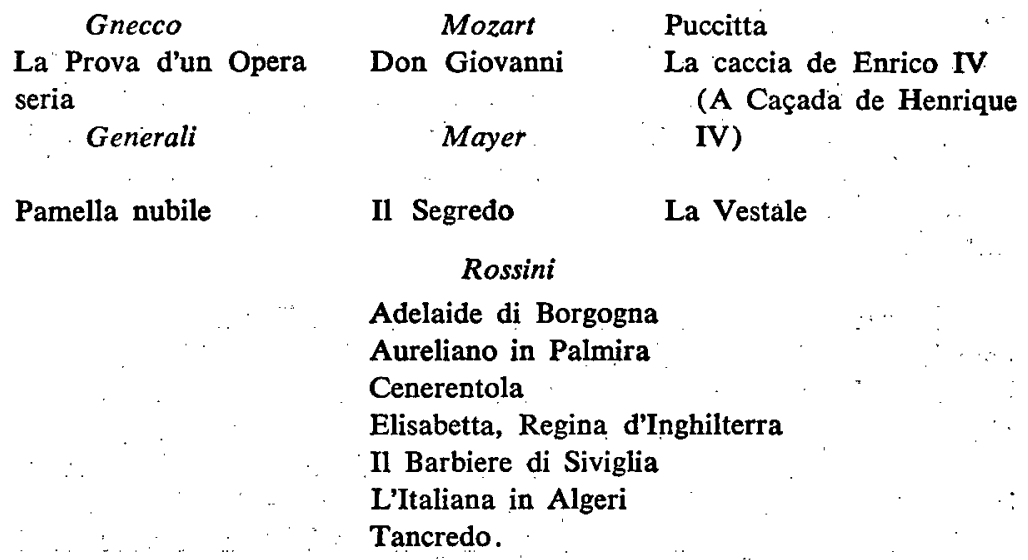


Em 1829 apresentou-se em Buenos Aires, com estadia prévia em Montevideo, vindo do Rio de Janeiro, a Companhia Schieroni, trazendo à sua frente a famosa contralto Teresa Schieroni. Representava este elenco principalmente óperas de Rossini, seguindo logo para Santiago de Chile, Lima e o Oriente. Na troupe da Schieroni achava-se Domingo Pizzoni, primeiro baixo cantante, Margarita Caravaglia, contralto Teresa Schieroni, do mesmo registro de voz, Joaquim Vitelli, baixo cantante e Augustín Miró, tenor. A Schieroni, após grandes sucessos na Itália, atuou na Espanha, cantando em Barcelona, na temporada de 1823, com êxito enorme, na ópera de Mercadante, Elisa e Claudia, e na de Rossini, Zelmira, em 1824. Em 1826 achava-se em Lisboa, passando logo para o Rio de Janeiro, exibindo-se em Tancredo, La Cenerentola, La Italiana in Argeli e na Gazza ladra. Em 1823 fez-se ouvir em Buenos Aires o jovem violinista Luis Cerfílio Planel, oferecendo vários concertos em meados desse ano. Teve muito sucesso e segundo notícias publicadas no tão informativo British Packet, jornal publicado em língua inglesa em Buenos Aires, iniciou-se como regente de orquestra do Corps de Opéra ambulant de Teresa Schieroni, atuando no Chile, Peru, India e China, fazendo-se ouvir também como virtuose de violino. E duvidoso que tenha sido parente da família Planel estabelecida em Montevideo, e da qual falaremos mais adiante.

Naqueles anos já foi difícil para Rosquellas reunir elementos locais ou de trânsito para representações completas de ópera. Em determinada ocasião o fez com um grupo de cantores franceses. Também chegou a Montevideo e Buenos Aires a soprano italiana Justina Piacentiní, dando a conhecer pela primeira vez óperas de Bellini. Veio do Rio de Janeiro onde atuou no São Pedro de Alcântara junto com o seu pai, Fabrício Piacentini, e as duas irmãs: Elișa, que casou com o filho do barítono Miguel Vaccani e Carolina, bailarina de certo nome. De mais uma, Isabel, não se deu notícia nos jornais de Buenos Aires. Fabrício, cantor bem conhecido. na Itália, morreu no Rio de Janeiro a 13 de novembro de 1829 , depois de ter feito estréia, com as suas filhas, da Gazza ladra e La Cenerentola de Rossini. A propósito da sua atuação, o Jornal do Comércio do Rio de Janeiro dizia que foi o melhor artista que veio atuar no Teatro da Capital do Império.

Deveríamos referir-nos agora aos irmãos Tanni que integraram, com Miguel Vaccani, Caetano Ricciolini e Juan E. Viera, mulato de Lima estabelecido em Buenos Aires, o primeiro elenco ou companhia lírica que fez estréia de óperas completas na Argentina. Os Tanni atuavam com o Vaccani no Rio de Janeiro quando sobreveio o incêndio do Teatro São João a 25 de março de 1824. Eles tinham sido contratados por Rosquellas, chegando vários membros da famí- 
lia Tanni e Vaccani no mesmo navio. Angelita Tanni, tal foi o diminutivo dado à Angela em Buenos Aires, tinha em 1823 desesseis anos. Soprano ligeira, o público a idolatrava. Ela casou-se com um cavaleiro portenho, mas ficou viuva muito cedo. Atuando logo em Montevideo, de 1830 em diante, para onde transladou-se com quase toda a família, casou-se de novo com um senhor Cunha, brasileiro, gerente do Banco Mauá. Maria Tanni veio acompanhar a sua irmã desde o Rio de Janeiro, mas não possuia, como cantora, as elevadas qualidades de Angelita. Após certo tempo, voltou para o Rio de Janeiro onde tinha família. Regressou em 1829 a Buenos Aires, vindo com o seu irmão Francisco Tanni, pianista e regente de orquestra que já se tinha incorporado na primeira viagem ao grupo familiar. Pasqual Tanni, barítono, foi possuidor dum extenso registro; similar ao de Vaccani e cantou na Capela Real juntamente com o seu irmão Paschoal, tendo ingressado os dois em 1816 na sua condição de castrati. Pasqual tinha especial vocação pela música religiosa e dedicou-se posteriormente ao ensino do canto em Nova Fribourgo e Cantagalo, onde faleceu em 1860. Foi citado pelo Vincenzo Cernicchiaro na sua Storia della Musica nel Brasile. Marcelo Tanni deu em Buenos Aires alguns motivos para comentários escabrosos que cessaram logo perante a evidência de tratar-se dum grande sopranista, de uma doçura de voz sem igual. Foram os Tanni que integravam o elenco na estréia argentina do Barbeiro de Sevilha. O papel que eles desempenharam em Buenos Aires e Montevideo foi o de verdadeiros pioneiros, guiados pela competência dum Rosquellas.

Devemos ainda falar do grande barítono italiano Miguel Vaccani. Nasceu em Milão em 1770 e foi festejado na Europa em importantes cenários. Ouviu-o o General Iriarte na Ópera de Barcelona em 1805 e no São Carlos de Lisboa em 1808 . Veio para o Rio da Prata, onde atuou alternando com o Rio de Janeiro e Montevideo. Em 1827 cantou nesta última cidade perante a Missão Muzzi, integrada por altos Prelados, figurando entre estes o Cônego Mastai Ferretti, mais tarde elevado ao Pontificado como Pio IX. Vaccani estabeleceu em Buenos Aires uma Academia de ballet com a sua senhora, Maria Cândida, e com o filho do casal, um excelente bailarino que casou com a cantora Elisa Piacentini. Em 1830 regressou ao Rio de Janeiro, de 1833 até 1836 atuou em Montevideo, partiu de novo para a Capital do Brasil e voltou definitivamente ao Prata em 1838. Dizia-se que fisicamente era muito parecido com Luís XVI de França. Cantava com frequiência em dueto e dançou com sua mulher um Duetto dançante, com lundú, em português, que agradou tanto que o público pediu insistentemente o bis, segundo o jornal de Buenos Aires, British Packet, do dia 17 de janeiro de 1829 . A propósito do lundú devemos fazer uma segunda referência desta 
dança, interpretada decentemente nos salões e não poucas vezes em forma lasciva quanto mais próximo se achava dos níveis populares e particularmente, dos afro-brasileiros. No jornal El Pampero, de Montevideo, a 5 de fevereiro de 1823 , publicou-se uma crítica severa sobre a atuação de Juan Aurélio Casacuberta, um dos maiores atores latino-americanos da época e consumado bailarino, junto com Bernabé e Petronila Serrano, "pela sua indecência para bailar o despreciável e obsceno ondú". A Serrano foi atriz consular do teatro uruguaio entre 1800 e 1850 . Não sabemos se o Lundú, transformado no Uruguay por deformação em ondú, apareceu somente quando o período cisplatino, trazido pela tropa ou outra gente brasileira, de 1817 em diante. Também poderia ter vindo diretamente com bailarinos procedentes do Rio de Janeiro.

Para concluir as referências sobre Miguel Vaccani, podemos acrescentar que em 1851 recebeu uma grande homenagem na Casa de. Comédias em Montevideo, e em 1852 cantou para o seu benefício no Teatro de la Victoria, e em 1865, no Teatro Argentino, os dois de Buenos Aires. Parece incrível - e acreditamos tenha sido o único caso universal no reinado do canto, - que aos 84 anos ainda tivesse voz para se apresentar com possibilidades de êxito perante 0 seu auditório. Deve ter morrido em Montevideo em 1860. Dizia-se, segundo as Memórias de V. Mansilla, que nos seus últimos anos formou um preto que cantava e dançava.

Em 1828-29 chegaram também, procedentes da Itália, mas com atuações no Rio de Janeiro, os cantores Luis Foresti (Bérgamo, 1790 - Salvador da Bahia, 1849), e a sua esposa, a soprano Maria Fratellini de Foresti. A Maria Foresti estreiou com a contralto Maria Teresa Schieroni, em 1828, e ao que parece, com Luis Foresti em 1829. Tinha voz de barítono muito ampla, pudendo atuar de baixo; foi professor de canto, piano, harmonia e composição e estabeleceu-se mais tarde com Escola de Música em Montevideo, especializando-se "para ensinar a tocar o piano às pessoas de mão pequena", uma técnica que mereceu aprovação do Conservatório de Bérgamo e do famoso Simon Mayr. A sua esposa faleceu em Montevideo em 1834 e aos poucos, Foresti casou com Manuela Sarogue. Atuou repetidas vezes com Miguel Vaccani e Justina Piacentini. Em 1838 estabeleceu-se em Salvador da Bahia, onde faleceu em 1849 em conseqüência da febre amarela.

Devemos citar aqui outro caso de "transplante" de músicos. Roque Rivero, pianista argentino, foi um dos tantos emigrados que fugiu da tirania de Rosas. Estabelecido em Montevideo, desenvolveu grande atividade como compositor de pequenas obras para piano, e canto e piano sobre textos dos poetas refugiados no Uruguai e logo 
incorporados quase todos eles definitivamente ao país, outros voltando à Argentina uma vez desaparecida a ditadura de Rosas, como Bartolomé Mitre, Juan María Gutiérrez, Juan Cruz Varela, Rivera Indarte e muitos outros. Escreveu música cênica para o Teatro, a chamada Casa de Comédias, colaborava no jornal El Talismán e dedicou-se decididamente à composição, até o ano 1843, em que subitamente desaparece, sem deixar rastro algum. Não seria demais pensar. que viajou junto com o seu filho para o Rio de Janeiro, onde deve ter morrido quase imediatamente após a sua chegada.

Este filho, Demétrio Rivero, ficou em Buenos Aires até 1839, indo também para Montevideo nesse ano. Tinha estudado com o seu pai, com o regente da Orchestra do Coliseo Provisional, Pedro Antônio Fernández, e com o alemão Felipe Seyder. Aos 10 anos, em 1832, apresentou-se em público, tocando com Federico Planel, o pianista e violinista uruguaio, irmão da esposa do Santiago Massoni, que the deu excelente formação. Tocavam estes jovens o Concerto de Kreutzer para dois violinos. Poucos anos mais tarde soube interpretar as Grandes Variações de Bériot. Estabelecido em Montevideo, fez-se ouvir com o pai, que era um notável pianista, na Casa de Comédias, onde atuou logo como violinista,, regente e compositor. Em 1843 passou para o Rio de Janeiro, onde foram alunos seus, entre outros, Francisco Carvalho, Joaquim Maria, Guilherme de Oliveira, e Vicenzo Cernicchiaro. Foi violino spalla no Teatro São Pedro de Alcântara e durante trinta anos Professor da Escola Nacional de Música. Era Cavaleiro da Ordem da Rosa. Participou, no início das suas atividades, na Orquestra da Capela Imperial, a partir de $1844 \mathrm{e} \mathrm{em}$ 1848 foi convidado por João Caetano para a posição de violino-regente da orquestra que tocava no Teatro São Januário nas representações dramáticas. No mesmo ano foi nomeado violino-regente do Ginásio Dramático, do qual foi proprietário o famoso ator português Luís Cândido Furtado Coelho, e em 1859, secretário do Conservatório (posteriormente Escola Nacional de Música), sustituindo o falecido Francisco de Mota. Como compositor de obras para violino, dedicou à célebre atriz Augusta Candiani, no seu benefício em agosto de 1845, um Tema com Variações. Quando veio o violinista português Fernendo de Sá Noronha, em 1849, executou o Tremolo de Bériot, sendo acompanhado por Demétrio Rivero, Ribas, Warneck e Preti no concerto que deu em 16 de janeiro deste ano. Rivero foi autor duma ópera $O$ Primo da Califórnia, apresentada em 1855, e de numerosas obras menores, modinhas, romanzas e noturnos que editou na Casa Arthur Napoleão. Quando se realizou o enterro do célebre Louis Moreau Gottschalk no Rio de Janeiro, a 19 de dezembro de 1869 , partindo da sede da Sociedade Philarmônica o préstito para o Cemitério de São João Batista, Demétrio Rivero se achava nos primeiros 
lugares da imponente manifestação de pesar que convulsionou o Rio de Janeiro. Faleceu em março de 1889 na capital brasileira, profundamente estimado nos meios sociais e artísticos.

Desde as últimas atuações de Rosquellas até 1832, propriamente, não houve representações de óperas inteiras, e até os concertos com fragmentos líricos, consistentes em árias e duetos minguaram muitíssimo. Veio Justina Piacentini atuando desde $1832 \mathrm{com}$ outros elementos do bel canto, dos quais não poucos devem ter feito breve, ou talvez prolongado estágio no Rio de Janeiro, segundo as circunstâncias do meio artístico achados na Capital. Em 1835 veio do Brasil o segundo grande virtuose de violino após o estágio de Massini, Carlos Bassini. Nasceu em Nápoles em 1814 e foi professor do Real Conservatório dessa cidade e membro das Academias Filarmônicas de Palermo e Messina. Antes de vir para a América do Sul atuou com grande sucesso na sua cidade natal, Gênova, Turim e Paris. Chegou ao Rio de Janeiro com a idade de 22 anos, e obteve aplausos apoteóticos com as Variações de Paganini sobre a quarta corda. Fez escala em Montevideo, onde se apresentou em novembro-dezembro de 1834. Logo após obter grandes triunfos em Buenos Aires, viajou para o Chile e Peru, sofrendo na sua volta um naufrágio em frente de Valparaíso, perdendo todos os seus bens. Reapareceu em Buenos Aires em 1837, dando a conhecer um triste, Ven a mis brazos, ven e umas Variações sobre o Cielito.

Os anais dos acontecimentos musicais do Rio de Janeiro ainda se acham longe de terem sido exaustivamente removidos para se obter um máximo de informação e é neste sentido que faltam notícias sobre atuações de artistas líricos e virtuoses que vinham da Europa ou voltavam de Buenos Aires e Montevideo para idêntico destino. Outros, já estabelecidos numa destas duas capitais, confiando na sua capacidade interpretativa, procuravam em viagens breves recolher aplausos nas terras brasileiras. Parece que o flautista José María Cambeses, espanhol, esteve no Rio de Janeiro em 1821, oferecendo um concerto no $\mathrm{n}^{\text {o }} 17$ do Largo do Rocio, que parece ter sido uma casa de família. Ayres de Andrade deu-lhe nomes errados, chamando-o de João Manoel. Virtuose no seu instrumento, começou a atuar em Buenos Aires em 1830. Onde pode ter permanecido este homem em todo este lapso de tempo? No Arquivo da Igreja de São Francisco de Montevideo, que passou logo à Seção de Musicologia do Museu Histórico Nacional, acham-se Variações para flauta só, uma Introduçāo e Jota Aragonesa, um Tema com variações, e duas Variações, uma sobre a Cenerentola de Rossini e outra sobre Donna Caritea de Mercadante. Deve ter sido muito prolífico. Fazia-se ouvir sempre nos intervalos das representações líricas. 
Um elemento muito destacado, diretor de orquestra e de espetáculos, um dos últimos representantes da Tonadilla cênica, foi Antônio Sáenz, chegado a Montevideo para reger as atividades musicais da Casa de Comédias em 1829, também vindo do Rio de Janeiro, precedido da fama de tocar com suma habilidade onze instrumentos de sopro e de corda. Como nada da sua passagem e estadia na terra carioca existe registrado até hoje, podemos dizer que voltou a ela em 1845, apresentando-se como primeira rabeca de alguns teatros da Europa e de América, tocando as Variações de Paganini na quarta corda não com o arco, mas com uma bengala e exibindo-se com 14 diferentes instrumentos por ele tocados. Como compositor, bastante prolífero, escreveu também um Hino Nacional do Uruguay que se perdeu.

Figura por demais interessante foi o violoncelista e pintor francês Amadeo Gras. Nasceu em Amiens, a 6 de maio de 1805 e faleceu em Galeguaychú, Argentina, a 13 de setembro de 1871 . Realizou estudos de pintura e música em Paris, atuando já em 1824 como primeiro violoncelo da orquestra da Opera. Em junho de 1827 chegou pela primeira vez a Buenos Aires, onde atuou nas tertúlias e na orquestra do Coliseo Provisional dirigida pelo violinista Massoni. Logo após uma breve estadia com Massoni no Chile, regressou para França. Em 1830 achava-se na orquestra do King's Theatre de Londres, acompanhando Paganini em várias récitas. Em meados de abril embarcou novamente para Buenos Aires, onde chegou a 6 de junho. Aos poucos se apresentou ao público, sendo secundado no seu concerto por Rosquellas. Após várias atuações nos salões de Buenos Aires ausentou-se, viajando entre 1833 e 1845 pelo interior da Argentina e por países vizinhos, oferecendo concertos de violoncelo e realizando uma atividade fecunda como pintor retratista. Em 1834 vinculou-se em Sucre com Rosquellas, participando nos concertos que este organizava na Sociedad Filarmónica por ele fundada. Durante o Sítio de Montevideo ofereceu concertos na cidade e no acampamento do Gereral Oribe. Quando Sivori visitou o Rio da Prata em 1850, acompanhou-o da mesma forma como o fez em Londres com Paganini. Em 1860 fundou em Buenos Aires a Sociedad Unión Musical, oferecendo vários concertos no Teatro Colón e quando chegou Louis Moreau Gottschalk a Buenos Aires em fins do 1867, Gras colaborou também com este artista, ajudando-o na organização dos seus concertos. Viveu desde 1854 em Gualeguaychú, onde faleceu em 1871. Os seus restos mortais foram trazidos para o Cemitério da Recoleta, de Buenos Aires.

E interessante mencionar que Amadeo Gras casou em 1833 em Montevideo com Carmen Baras, que lhe deu 12 filhos. Estabeleceu 
na capital uruguaia uma oficina de Daguerreotipo, permanecendo aí cerca de três anos, e voltando a esta cidade com o propósito de dar concertos com alguma frequiência, inclusive com Sivori. Não achamos o menor registro sobre atividades profissionais de Amadeo Gras no Rio de Janeiro. Cabe acrescentar que pintou para mais de 2.000 retratos na sua vida de andarilho.

Um outro elemento de destaque foi o violinista Federico Planel, que nasceu a 11 de maio de 1822 em Montevideo, filho de Luis Antônio Planel e D. Luisa Calmet, os dois naturais da França. Já mencionamos que a irmã de Federico achava-se casada com Santiago Massoni, e foi este que se ocupou com a formação musical do menino. Aos 5 anos já começou a ser apresentado nos salões de Montevideo e em 1833, seus pais, que também eram musicistas, empreenderam viàgem para Lima. Havia atuado em Buenos Aires já em 1832 e voltou a esta cidade em 1834. Tocava indistintamente o violino e o piano com grande habilidade. Com breves atuaçổes em Valparaiso, regressou ao Uruguay, para empreender em seguida viagem para o. Rio de Janeiro, onde se fez ouvir com um concerto de Rode e um Tema variado de Wranitzky. Diz Ayres de Andrade que se fazia acompanhar nesta ocasião pelo seu irmão Teófilo, do qual não dá informação alguma Lauro Ayestarán na sua obra La Música en el Uruguay. O mesmo Ayestarán diz que perdeu a pista de Federico Planel logo depois da sua atuação no Rio de Janeiro, no Teatro Constitucional Fluminense, mas sabe-se que os dois iam matricular-se no Conservatório de Paris, para onde se dirigiam. Cabe, pois, pesquisar nos arquivos da vetusta instituição parisiense, se houve uma passagem dos dois uruguaios pelas suas aulas.

Justina Piacentini, chegada ao Rio de Janeiro, em 1828, como dizíamos, com o seu pai Fabrízio e as suas irmãs Elisa e Carolina, veio em abril de 1832 para Buenos Aires, dedicando-se com especial ênfase às obras de Bellini e Donizetti, fase operística de estilo intermédio entre o de Rossini e o de Verdi. Cantou na Casa de Comédias de Montevideo ininterruptamente até 1839 , mas viajando com frequiência para Buenos Aires. Quando estourou a Grande Guerra, voltou para o Uruguay, estabelecendo-se com Conservatório de Música no subúrbio do Cerro.

Um terceiro virtuose de violino chegado às nossas plagas foi Agustín Robbio, também italiano, que voltou pela segunda vez ao Prata em 1875. Em Buenos Aires apresentou-se com a Companhia de Ópera de Antônio Pestalardo, quem veio ao Brasil em 1845, permanecendo no Rio de Janeiro prolongados anos até se radicar definitivamente em Buenós Aires, onde foi em seguida, empresário do 
Teatro de la Victoria (1848-51), do Teatro Argentino (1853-55) e do antigo Teatro Colón (1864-67), tendo contribuido notavelmente pelo desenvolvimento da música artística argentina, superando, aos poucos, Buenos Aires o nível do Rio de Janeiro.

$\mathrm{O}$ tráfego musical entre as três capitais ia aumentando gradativamente. Em começos de 1838 chegou do Rio de Janeiro o tenor italiano Vittorio Isotta, que teve uma boa atuação nos teatros do Rio de Janeiro desde 1833; em setembro de 1848 veio Nina Barbieri, o seu esposo Juan Thiolier, cantor, Juan Barbieri, irmão da Nina e o tenor Pablo Sensati, todos eles com atuações prévias nos teatros fluminenses. Nina Barbieri nasceu em Florença em 1820. Era filha de um funcionário do Grão-Duque da Toscana, realizou estudos com Luigi Barbieri em Florença e com Giuditta Pasta em Milão. Debutou em 1843, cantando Lucrecia Borgia, atuando imediatamente com grande sucesso nos principais teatros da Itália. A temporada que ela desenvolveu no Teatro Régio de Parma foi um acontecimento notável. Verdi escreveu para ela a parte feminina das suas óperas $I$ due Foscari (1848), Macbeth (1847) e Il Corsaro (1848). Atuou nos Teatros de Barcelona e Macirí e chegou ao Rio de Janeiro, precedida de grande fatna de ter sido cantora de Câmara do Grão-Duque da. Toscana em 1847. Era possuidora duma voz brilhante e de grande extensão assim como de magníficas condições para o gênero dramático, fazendo ostentação de acentos patéticos e de slanci appasionati :

Em dezembro de 1846 chegou a Buenos Aires a família de músicos integrada por José Uguccioni, nascido na Itália em 1815. Foi violinista, assim como os seus filhos José (1840-1890) pianista, e Alejandro (Barcelona 1840 - Montevideo, 1895) violinista. A sua atuação no Teatro de la Victoria, foi muito aplaudida, particularmente a de Alejandro, o violinista, que tinha naquela ocasião apenas seis anos, voltando a Buenos Aires aos 17 anos de idade. Em 1848 chegou a Buenos Aires o violinista italiano Agustin Robbio, depois de ter atuado com grande sucesso nas cortes de Madrí e Rio de Janeiro, que se dizia também aluno de Paganini. Um cronista exaltou, no Rio de Janeiro, a sua capacidade de imitar

"o gorjeio dos pássaros, o relincho dos animais, o chiar dos carros transportando madeira"

e outras belezas. Em Buenos Aires atuou no Teatro de la Victoria e em Montevideo na Casa de Comédias. Foi violinista espetacular. No seu repertório não faltava o "Carnaval de Veneza" de Paganini. Voltou novamente ao Prata, seguramente também ao Brasil, en 1875. Seguiu-se-lhe o violinista alemão Augusto Luis Moeser, nascido em 
Berlim em 1825; vinha precedido de muita fama pelas suas atuações na Europa, tendo sido muito elogiado por Berlioz. Era afilhado do Barão de Humboldt, e trazia os títulos de concertista da Corte real da Dinamarca e Hannover. Foi, como anteriormente, Sigismundo Neukomm, um dos primeiros em inspirar-se em motivos dos paisagens do Rio de Janeiro, escrevendo uma valsa $O$ Pão de Açúcar, executada nos seus concertos em cena aberta, pela orquestra. Autor duma Introdução, Tema, Variações e Finál para a quarta corda, um jornal carioca anunciava que

"Antes de principiar esta peça, o Sr. Moeser tirará do Instrumento as outras três cordas perante o público".

Este era o período do virtuosismo vazio, obrigatório para se exibir perante auditórios ainda pouco exigentes, ao menos na sua maioria, assim como foi também o século da apresentação dos "prodígios musicais". Foi muito aplaudido em Buenos Aires com as suas apresentações no Teatro de la Victoria. Entre o seu repertório figuravam Variações sobre temas da ópera Il Pirata, uma Cadencia sem acompanhamento, Variações composta por ele para Paganini e, como cavalinho de batalha, os motivos sobre $O$ Carnaval de Veneza. Ele deve ter sido muito bom músico. O pai foi diretor da Orquestra Real de Berlim e membro do Quarteto dessa capital; em 27 de novembro dirigiu pela primeira vez a execução da Nona Sinfonia de Beethoven em Berlim, e em setembro de 1845 participou nas festividades em Bonn por motivo da inauguração do monumento a Beethoven. Moeser filho possivelmente seguiu para o Chile. Em 1851 atuou com grande sucesso em Bogotá, falecendo durante uma tournée nos Estados Unidos em 1859. Dele foram impressas várias obras para piano.

Neste mesmo ano veio também ao Rio da Prata, procedente do Rio de Janeiro, o violinista Carlos Wynen, que, no final dos seus concertos, tocava uma Grande Fantasia sobre motivos de Guilherme Tell, e num instrumento russo, de palha e madeira, chamado Yerowa e Salamo. Foi aluno de Charles Bériot no Conservatório de Bruxelas em 1843. Tinha atuado no Brasil em 1846 e quando tocou em Lima, no mês de abril de 1847 apresentou-se no Teatro principal desta capital como violinista de $S$. $M$. el Emperador del Brasil. Cernicchiaro o elogia muito na sua Historia della Musica nel Brasile, como representante de alta escola e forte temperamento. Num violento temporal, em viagem para Oriente, foi lançado à praia da Bahia, perdendo toda a sua bagagem com exeção do seu violino e o repertório musical. Deu também concertos na Bahia, sendo aplaudido no Brasil pela interpretação da Grande Fantasia Lembranças de Bellini, de Artot. No Rio de Janeiro deu o seu último concerto em 25 de agosto de 1846 com enorme sucesso e no dia seguinte, o Imperador D. Pedro II o 
obsequiou com um anel de brilhantes com a uma dedicatória. No Jornal El Progreso de Santiago do Chile, de 4 de abril de 1843, se publicou uma descrição de instrumento Yerowa e Salamo:

"Se compõe de tantos pedaços como teclas de piano, naturais e bemois, todos ensartados por um fio que os liga a outros e os ordena de maior a menor: As teclas, poderíamos dizer; são percutidos com uns martelos pequenos de madeira negra, dura. E um instrumento russo".

Geralmente, os violinistas virtuoses chegados à América do Sul atuavam também como regentes dos elencos líricos. Quando o empresário Pestalardo organizou em 1848 a Companhia Lírica, Robbio foi designado como regente e como este tinha dirigido vários espetáculos de óperas, devendo continuar viagem, tomou o seu posto o belga Wynen. O concertista Robbio apresentou-se também em Montevideo e voltando para o Brasil, passou para a Europa atuando em Paris, Berlim e Londres. Voltou novamente após 27 anos de ausência, radicando-se em Buenos Aires. Em 1877 partiu definitivamente, realizando uma tournée pelos países do Pacífico e Estados Unidos. A última notícia que dele se deu nos jornais portenhos foi uma referência à sua atuação no Albert Hall de Londres.

O quinto virtuose do violino, e certamente o maior de todos, foi Camilo Sivori. Contrariamente aos outros musicistas viajantes, fez uma inversão no itinerário do seu trajeto artístico, descendo pelo lado do Pacífico. Menino prodígio, nasceu em Gênova em 1815, falecendo na mesma cidade em 1894. Foi discípulo de Paganini, que compôs para o pequeno Sivori um Concerto e Seis Sonatas para violino com acompanhamento de guitarra (violão), viola e violoncelo. Aos dez anos começou a sua carreira de concertista, apresentando-se em Paris na Sala Chantereine, em 1828, acompanhado ao piano por Liszt. Percorreu a Europa inteira desde 1828 até 1845 , embarcando em seguida para os Estados Unidos, descendo depois para o México e Panamá. Havia estado também em várias ilhas do Caribe. Atuou em seguida em Lima, Santiago do Chile e Valparaiso. Nesta cidade embarcou numa fragata inglesa que o levou diretamente para o Rio de Janeiro e somente após os seus concertos no Brasil veio para o Rio da Prata. Incorporou ao seu repertório Variaçóes sobre o Yankec Doodle, outras sobre um tema de Zamacueca chilena, escreveu $E l$ Canto del Sinsonte, no qual introduziu melodias recompiladas na sua viagem e El Carnaval de Cuba. Nos seus programas não faltavam jamais as mais difíceis peças de bravura de Paganini. Na Argentina tocou perante Rosas, a sua família e os seus adidos, mas o ditador manifestou logo a sua grande preferência pela guitarra. 
Aqui pomos fim à relação dos instrumentistas do violino, para dedicarmos conclusivamente à cena lírica. E como Sivori atuou em 1850 , praticamente damos fim ao nosso passeio pelo mundo musical nascente dos nossos países banhados pelo Atlântico. Em janeiro de 1849 incorporou-se à companhia italiana" em Buenos Aires, Carolina Merea, sustituindo a Barbieri por achar-se esta doente da garganta. Esta artista teve na capital argentina um enorme êxito. Veio do Rio de Janeiro e cantou em seguida em Montevideo e Lima, entre 1850 e 1851, regressando novamente à capital portenha em 1855. O jornal La Crónica, dedicou-lhe um comentário a 21 de setembro de 1855 , que não foi outra coisa que a reiteração de conceitos vertidos durante a sua primeira estadia:

"La Merea. Chegou esta simpátia artista, que em época de grata lembrança levou à loucura este povo com os seus trinados de vibrante e puríssimo canto".

Da sua atividade no Rio de Janeiro possuimos escasíssima informação. Um outro elemento, Ângelo Lagomarsino, pertencia ao elenco do Pestalardo. Nada sabemos sobre a sua passagem pelo Rio de Janeiro. Atuou também na Casa de Comédias de Montevideo, desde 1834 até 1851 , alistando-se durante o sítio da cidade nas hostes da Legião Italiana, comandada pelo General Garibaldi. Naturalmente, o: nomes de artistas que viajavam de uma para outra das capitais dos três países, formavam já em meados do século XIX verdadeira legião e nem todos podem ser citados, ainda mais porque, como já foi dito reiteradas vezes, a informação do lado brasileiro é fraquíssima, mesmo com um exaustivo levantamento. Durante a temporada de 1849-50 chegaram mais artistas que se incorporaram à companhia de Pestalardo: Pablo Franchi, Clemente Mugnay, Teresa Questa, Luisa Pretti, José Maria Ramonda e Carlos Rico. Em janeiro de 1851 chegou às plagas portenhas a soprano Ida Edelvira, que foi a cantora preferida do público de Buenos Aires entre 1851 e 1855. Nasceu na Itália nos anos 20, debutou em Madrí como primeira dama com Ernani, foi logo contratada:em Paris, mas o maestro Giannini a levou para o Rio de Janeiro em 1849, debutando no começo de $1850 \mathrm{com}$ Roberto d'Evreux de Donizetti Em outubro de 1855, quando acabou de cantar em Buenos Aires La Favorita, foi-lhe oferecida uma coroa de loureiro integrada por 44 folhas, levando inscriptas em cada uma, com letras douradas, as 44 óperas que ela cantara em Buenos Aires. Iniciou nesse ano uma viagem a Rosário, onde deu várias récitas; passou ao Chile e outros países do Pacífico para, regressando à capital argentina. em 1858, logo em seguida partir definitivamente para Europa, morrendo na Itália em 1874. Devemos acrescentar que ela atuou também com frequiência em Montevideo, onde foi considerada a mais preponderante das cantoras desse período. 
Para finalisar com este período podemos aduzir que em princípios de 1838 apresentou-se em Buenos Aires o tenor italiano Vittorio Isotta, que atuou com o.barítono Vaccani e outros artistas no Rio de Janeiro. Em setembro de 1848, ainda na época do Ditador Rosas, que deixou praticamente fechado o Coliseo Provisional num período de quase 18 anos, chegaram destacados cantores italianos que atuaram no Rio de Janeiro durante vários meses: a soprano Nina Barbieri, o seu marido, o cantante Juan Thiolier, o irmão da primeira, Juan Barbieri e o tenor Pablo Sensati.

\section{Considerações finais.}

As linhas que antecedem, possivelmente cansativas pela inumeração constante de nomes e mais nomes de virtuoses, cantores e cantoras, representam um período de formação artístico-musical dos nossos países, sobre o qual devemos meditar para apreciar devidamente a singularidade duma série de esforços extraordinários, levados a efeito, na maioria dos casos, por estrangeiros que se achavam em trânsito. Muitos ficaram, sentindo-se impelidos a tentar a sorte em meios novos, estabelecendo-se geralmente com uma Academia de Música ou atuando individualmente como professores desta arte, cada um na sua especialidade.

O Rio de Janeiro é um fabuloso exemplo de sedimentação desses grupos e da incorporação deles, temporária ou permanentemente, a um meio que lhes deve ter parecido simpático e promissor. Há na História da Música no Brasil terríveis lacunas sobre o processo pormenorizado deste constante fluxo e refluxo que trouxe ao país, e particularmente ao Rio de Janeiro, como capital musicalmente mais desenvolvida, e devido o crescimento constante da sua população dedicada à arte da música, sendo na sua maioria italianos. Foi assim que se fizeram no século XIX todos os ambientes da América Latina e dos Estados Unidos; embora a imigração dos músicos neste país fosse principalmente nórdica. Teríamos gostado continuar um esforço dedicado a estas pesquisas, quando escrevemos a obra Vida y Muerte de Louis Moreau Gottschalk no Rio de Janeiro (1869). El Ambiente musical en la Mitad del Segundo Imperio (16). A pesquisa foi escrita originalmente em português e destinada ao Boletín Latino-Americano de Música, do qual saiu no Rio de Janeiro sob nossa direção, com muitas dificuldades, o volume VI, com as suas 610 páginas em

(16). - Universidad Nacional de Cuyo, Departamento de Musicología, Mendoza, $1950-51$. 
grande formato, inúmeras ilustrações e exemplos musicais e um robusto Suplemento Musical. Durante o processo de lançamento deste primeiro volume, o autor preparou um segundo, o VI/2, já revisto em três provas, sem que se chegasse a um financiamento em extremo facil; somente coordenando vontades, esta segunda parte integrada com excelentes trabalhos teria sido publicada. Depois da nossa partida para o Uruguay, a obra ficou durante dez anos na Imprensa Nacional, sem que ninguém tivesse mostrado interesse por tão extraordinário documento sobre vários aspectos importantes da vida musical brasileira do presente e do passado. Foi finalmente destruido, voltando o chumbo da composição novamente à fundição $\mathrm{e}$ as inúmeras gravuras, de elevadíssimo custo, para o lixo. Cito este episódio como um dos tantos que apenas precisavam dum pouco de boa vontade para que os brasileiros houvessem podido desfrutar de mais uma valiosa contribuição ao passado tão pouco conhecido da sua história musical.

Sem uma pesquisa minuciosa e ao mesmo tempo honesta, embora se apresente difícil, será impossível conhecer-se fundamente este pretérito, as suas interconexões com os Estados do Brasil e com o Exterior, neste continuado vaivem das correntes de interesses artísticos. Muitos dos numerosos nomes das pessoas que citamos aqui, correspondentes ao período $1800-1850$, nunca os temos encontrado nos Anais da História musical do Brasil. Uma história não se forma apenas com vultos, senão com inúmeros "tijolos" (personalidades menores), que constituem o Todo dum edifício, dum ambiente. Sabemos perfeitamente que Haydn, Mozart, Beethoven e Schubert surgiram dum mar de elementos de menor categoria, embora de sólida formação. A razão do seu destaque, por cima de todos, não foi apenas a qualidade de gênio que possuia cada um dos grandes mestres, mas a presença de numerosos artistas que coadjudaram com a sua presença e ação, involuntariamente, na maioria dos casos, mas formando este Todo do monumento sonoro duma cidade, de um país. E bem sabido que os gênios não poderiam nem viver nem evoluir solitariamente. Muito do que eles lograram na sua vida, se deve primordialmente a um ambiente musical muito nutrido.

Insistimos no caso do Padre José Maurício Nunes Garcia. Seria incongruente supor que ele, como personalidade dotada do maior talento, houvesse sido um autodidata que se satisfazia aprendendo apenas com as partituras dos mestres clássicos italianos e alemães. Detrás desta oca suposição se acha alguém, ou vários, que deram a ele a formação básica, a que permanentemente está presente no criador, o métier, sem o qual a genialidade, ou um talento forte não poderia chegar a expressar-se livremente. Sabemos que o que menos foi in- 
vestigado no Brasil tem sido o ambiente musical anterior à vinda de João VI para o Brasil, ou, para ser mais preciso, para o de Rio de Janeiro. Assim como o Padre José Maurício deve ter tido excelentes mestres que lhe ensinaram, ele também viveu num meio circundante indubitavelmente mais elevado do que geralmente se tem sustentado nas histórias musicais brasileiras.

Indo mais para o fundo da História musical dessa nação, chegamos à presença dos compositores mulatos de Minas Gerais, atuando sem constrangimento com bons elementos que se achavam abundantemente ao seu dispor. Mas as suas composições revelam com toda evidência que houve quem lhes ensinasse não apenas cartilhas de música, mas todos os conhecimentos necessário para formar mestres. A escassa informação existente, - culpa exclusiva da desídia dos homens, - nos priva do prazer de ampliar informação sobre o meio musical anterior, porém, fica demonstrado através de recentes descobrimentos, aos quais vamos fazer referência em artigo separado, que o Brasil contava com brasileiros natos de impressionante saber teórico. Estes artistas se achavam esparsos nos centros mais desenvolvidos das artes, mas não lhes faltou a documentação necessária para se constituir em figuras de relevo. Assim foi nas Colônias mais empolgantes da Espanha nas Américas, e assim deve ter sido também no Brasil colonial, porque os antecedentes portugueses na arte musical se davam permanentemente a mão com os espanhois de todos os tempos.

Voltando ao século XIX, com o seu processo de secularização da música, podemos dizer o seguinte: Quando um artista embarcava num fragil navio dos que sulcavam os mares do Mediterrâneo, Atlântico, Caribe e Pacífico, aceitando inúmeras desconfortòs, não só encomendava a sua alma a Deus, mas também fazia previamente testamento em caso de deixar alguns bens materiais, mulher e filhos. Merecem admiração as viagens marítimas daqueles tempos nos quais ninguém sabia se voltaria alguma vez à terra natal. Não há muito, apareceu um formidável livro que fala dos músicos, reunidos em pequenas corporações (capelas, como se dizia), que percorriam o mundo inteiro, procedentes duma cidade que os produzia superlativamente $\mathrm{e}$ que pouco ou nada é conhecida, nem para os alemães. Chama-se Salzgitter e se acha nas escarpas das montanhas Harz, no centro da antiga Alemanha, encontrando-se hoje boa parte desta região detrás da Cortina de Ferro. De lá partiram, e nem sempre voltavam, os regentes com os seus componentes músicos, com a finalidade de reunir dinheiro para uma vida mais cômoda, oferecendo em terras distantes repertórios ainda não conhecidos, mormente da mesomúsica, ou seja, da que se achava no meio, entre as expressões do povo e a música 
erudita: Tinham por hábito levar diários, com observações muito interessantes sobre paisagens, travessias, e hábitos dos povos onde faziam ouvir os seus conjuntos sempre muito bem afinados. Alguns ficavam num lugar determinado, na Austrália, na Äfrica do Sul, nos Estados Unidos dạ América do Norte, no Canadá ou no México, não poucos morrendo de acidentes ou adoentandos pelo excessivo emprego dos instrumentos de sopro, particularmente no Trópico. Outros, por faltar-lhes uma ocupação regular, se viam obrigados a desempenhar outros ofícios. Infelizmente, o bombardeio que realizou-se sobre a cidade de Braunschweig (Brunswick), na Segunda Guerra Mundial, destruiu grande parte dos arquivos desses grupos que descendentes piedosos estavam guardando, pois levavam com a maior honestidade para a agremiação, uma contabilidade das despesas que pode ser qualificada de notável. Com a informação minguada, ainda assim vê-se a importância destas capelas de músicos aventureiros que partiam com uma coesão extraordinária, como conjuntos de sopro, ou conjuntos de harpas (constituidos geralmente por duas harpas acompanhados por instrumentos de sopro mais levianos). Destas Bandas o Brasil recebeu numerosos conjuntos que percorriam a extensíssima orla marítima, fixando residência nas cidades onde existiam possibilidades duma prolongada atuação. A chegada dos primeiros grupos começou quando ainda as Colônias dos alemães em Santa Catarina estavam longe de se formar, ou, mais tarde, de representar núcleos urbanos orgânicos, como os conhecemos hoje. Tocavam nas cervejarias para lazer dos freguezes, ou para bailes no mesmo local, anunciados profusamente nos jornais. Executavam música nos circos, nos jardins daquela época, apareciam nos dias patrióticos fazendo soar nos ares os Hinos da Pátria, nas homenagens às grandes figuras teatrais, como no caso da atriz Adelaide Ristori, ou para enterros, como aconteceu quando a inhumação dos restos mortais do Louis Moreau Gottschalk. U'ma descrição destes grupos de músicos, que também percorriam a Aıgentina, poderá talvez constituir tema para um próximo artigo, assim como a continuação dos intercâmbios musicais de $1852 \mathrm{em}$ diante, entre o Brasil e o Rio da Prata (17). Cabe explicar, que em 1850 e até antes, não houve sempre a vontade de percorrer, sendo possível, tudo o que hoje chamamos o cone sul do continente sul-americano. A famosa Rosina Stolz e a não menos ilustre Augusta Candiana, nunca viajaram em direção ao Prata. Creio que lhes satisfez sobradamente a calorosa acolhida que lhes brindou a todo instante a

(17). - Dieck (Alfred), Die Wandermusikanten von Salzgitter. Ein Beitrag zur Wirtschafts - und Kulturgeschichte des nördlichen Harzvorlandes; Göttingen, 1.962 . 
população carioca e não poucas das Províncias do Brasil, chamadas assim no período da Monarquia constitucional. A febre amarela, a peste bubônica, o cólera, numerosos barcos afundando, nada reteve a grei lírica, para se aventurar em pós da glória. Fora de dúvida, este período da atividade musical nos nossos países bem merece o epíteto de heroico.

Chalet Arapey, Punta del Este, 12 de Dezembro de 1975.

Nota: O autor deseja esclarecer que o trabalho precedente é fruto de pesquidas pessoais realizadas no correr de muitos anos e reunidos finalmente nestas linhas em forma sintética. Os trabalhos de Ayestarán, Andrade e Gesualdo, aqui citados, publicados posteriormente, apenas serviram para cotejos e retificações. 